\title{
Risk premium as an economic policy objective: the Spanish case
}

\author{
Indalecio Pérez• Pablo Castellanos* • José Manuel Sánchez-Santos
}

Department of Applied Economics I, University of A Coruña, Spain

Received: 31 July 2013

Revised: 4 October 2013

Accepted: 4 October 2013

\begin{abstract}
This paper tries to analyse to what extent the public debt yield spread of German and Spanish sovereign bonds is related with the Spanish economic fundamentals. An analysis of different Spanish economic variables (public debt/GDP, private debt/GDP, inflation rate, unemployment rate and borrowing capacity) from 1990 to 2012 is done previous to a cointegration analysis. Results do not allow us to confirm strongly the long term relationship between public debt yield spread and the referred economic variables as a whole null hypothesis. In this sense, there is not enough evidence to show that premium risk evolution is determined by Spanish economic fundamentals progression in the long term, and thus a speculative component might be considered as a determinant. Therefore, the referred spread role as an economic policy objective should be relativized since it cannot be proved that tackling the analysed economic variables could reduce the spread significantly.
\end{abstract}

Keywords: cointegration, economic policy, public debt yield spread, risk premium JEL Classification Codes: C12, C22, E43, E58

\section{Introduction}

Long term German public debt is widely used as a proxy for the profitability of a value without risk among UEM countries and thus, its spread with relation to other bonds yields of Eurozone economies (also known as 'risk premium') is analysed as a measure of the risk of a country (Favero et al., 1997; Düllmann and Windführ, 2000; Geyer et al., 2004; Fontana and Scheicher, 2010) ${ }^{1}$.

In this sense the risk premium has gained special prominence in the last years, becoming considered by some economists and politicians as an indicator of the effectiveness of economic policy measures. For instance, Mariano Rajoy, President of the Spanish

\footnotetext{
*Corresponding author. E-mail: pcg@udc.es.

Citation: Pérez, I., Castellanos, P. and Sánchez-Santos, J.M. (2013) Risk premium as an economic policy objective: the Spanish case, Economics and Business Letters, 2(3), 94-104.

${ }^{1}$ The long-term debt yield spreads have also been studied for other economies, such us the United States of America (Bernanke, 1990) and other countries (Eichengreen and Mody, 1998) or within the same country analyzing debt yields of regions against the central state debt yield (Schulz and Wolff, 2008).
} 
Government, stated recently ${ }^{2}$ that the results of the economic policy of his government, focused on reducing the public deficit, had allowed, among other things, to reduce the risk premium, which moved below 300 basis points, which means half the level of one year before.

Under these assumptions, this paper analyses the Spanish and German long-term debt yield spread and its relationship with other fundamental values of Spanish economy framed within the Economic Analysis carried out by the $\mathrm{ECB}^{3}$.

A risk premium determined by the evolution of the Spanish economic fundamentals would support the fact of acting on them in order to decrease it, while the opposite would point out that their behaviour could respond to a speculative component, relativizing the spread role as an economic policy objective ${ }^{4}$. In this sense, the results of a cointegration analysis carried out in this paper provide a judgment element in weighing the pros and cons of fiscal consolidation processes (intensity and rhythm) with the primary objective of reducing risk premium.

The structure of this paper is as follows. First of all, a range of series will be identified and described in order to be later used for unit roots and cointegration analyses. Second, a methodology section deals with the different econometric techniques used, either with or without structural breaks. Afterwards, the empirical estimates are presented in a summarized way, disclosing only the final results of the performed analysis. A final conclusion point closes the paper.

\section{Variables}

All the series used this paper are expressed on a quarterly basis, ranging from the fourth quarter of 1990 (4Q-90) to the second quarter of 2012 (2Q-12).

This period covers various relevant moments for the Spanish economy, such as the signing of the Maastricht Treaty ${ }^{5}$ in 1992 and the creation of the single currency (i.e., the euro) and the ECB in 1999.

The analysed variables were selected from a literature review and considering that their evolution could affect to the government bond yields spread:

-10 year bond spread -Spanish versus German- $\left(S_{\tau}\right)$

The spread value has been calculated as the difference between the Spanish and German government bonds yield to ten years in domestic markets.

- Public debt/GDP ratio in Spain $\left(D P U_{t}\right)^{6}$

The volume of public debt is considered as a measure of the financial solvency of a country (Nieto-Parra, 2009).

\footnotetext{
${ }^{2}$ Cinco Días, $8^{\text {th }}$ of May 2013.

${ }^{3}$ Economic Analysis is one of the two pillars of the ECB monetary policy strategy and it has the objective of evaluating the short and medium term prices evolution focusing on real activity and financial situation of the economy. See http://www.ecb.int/ecb/educational/facts/monpol/html/mp_004.en.html.

${ }^{4}$ There could be a paradox if premium risk decreases whilst economic fundamentals perform worst. This fact raises the interesting question of to what extent the level of the risk premium is determined by domestic economic factors on which policymakers can act.

${ }^{5}$ The Treaty on European Union (colloquially known as the Maastricht Treaty) was signed on February 7, 1992 and came into force on November 1, 1993. Among other things, it led to the launch of the European Economic and Monetary Union.

${ }^{6}$ Since this variable has the most restrictive set of data in origin since there are not data prior to the fourth quarter of 1990 available, this period will be taken as the beginning of the series for the rest of variables analysed, even if there were more values prior to that date for them. The values of these debt series were obtained through the Statistical Service of the Bank of Spain, which provides for these variables quarterly data from the third quarter of 1990.
} 
The value of the Spanish government debt used in this paper is the result of adding the central government, autonomous communities, social security administrations and the local government debts according to the Excessive Deficit Procedure (hereinafter, EDP) ${ }^{7}$. This debt is financed, inter alia, with government bonds.

The series used were relativized by the Spanish GDP series referenced in the Bank of Spain for calculating public debt following the EDP. This ratio has been identified as critical for explaining the differences in debt yield spreads (Aßman and Boysen-Hogrefe, 2009).

- Private debt/GDP ratio in Spain $\left(D P R_{t}\right)$

This ratio can be used as a proxy for measuring the private sector domestic solvency of a country, and, as such, it was incorporated into our analysis.

The value of the Spanish private debt used in this paper considers the loans to households, non-profit institutions and non-financial corporations. The GDP used as a reference is the same applied to the public debt ratio.

- Inflation rate in Spain $\left(I_{t}\right)$

The inflation of a country is a reference to the profitability of its public debt and thus higher inflation rates should be accompanied necessarily by higher returns on their bonds so that such debt seems attractive to investors.

Since the inflation rate used in this paper will be the rate or percentage of change in the general CPI in Spain ${ }^{8}$, which is provided on a monthly basis, this variable will be transformed on a quarterly basis ${ }^{9}$ in order to allow the comparison with all the remaining variables.

- Unemployment rate in Spain $\left(P_{t}\right)$

A job-destroying economy would cause an increase in the government debt yields, as a rising unemployment would reduce both the tax collection in the future and, furthermore, the possibility of the private sector to reduce its debt (if somebody had no job, his/her lack of income would make the amortization of bank loans difficult).

- Ratio (Current account balance+ Capital account balance)/GDP in Spain $\left(F_{t}\right)$

This ratio measures in relative terms the borrowing capacity of the Spanish government abroad (Donoso and Martin, 2010) and thus it is included among the variables analysed in the paper $^{10}$, since it gives an idea of the capacity of domestic savings to finance investment.

The value is calculated as the sum of the current account plus the capital account balance (calculated as the quarterly balance value) in proportion to the quarterly GDP in Spain (EDP basis).

\section{Methodology}

Cointegration tests have the objective to prove the existence of a long-term relationship between non-stationary variables with the same integration order (Engle and Granger, 1987; Enders, 2010).

\footnotetext{
${ }^{7}$ The definition of this debt was established by the Regulation (CE) $n^{\text {o }} 479 / 2009$ of the $25^{\text {th }}$ of May 2009 of the European Council.

${ }^{8}$ The CPI (Consumption Prices Index) is used in this paper instead of the Harmonized Index of Consumer Prices (HICP), which has no data available from the fourth quarter of 1990, starting date of the rest of the series analysed.

${ }^{9}$ The conversion of inflation series to quarterly data was performed using a simple average of the monthly values for each of the four quarters of each year.

${ }^{10}$ Although the references consulted analyse mainly the current account balance, we decided to include also the capital account balance in order to give a more complete picture of what should be considered as a borrowing capacity of a country. This procedure is also used in the statistics of the Bank of Spain. See http://www.bde.es/webbde/es/estadis/infoest/indeco.html.
} 
Thus, the model initially proposed to analyse the cointegration relationship could be formulated as follows:

$$
S_{t}=\beta_{0}+\beta_{1} D P U_{t}+\beta_{2} D P R_{t}+\beta_{3} I_{t}+\beta_{4} P_{t}+\beta_{5} F_{t}+\varepsilon_{t}
$$

where $\varepsilon_{t}$ is the error term.

If there is cointegration -i.e., if such series are not stationary but they have the same order of integration, and $\varepsilon_{t}$ is stationary-, we would prove the existence of a long-term relationship between the previously described economic fundamentals and the public debt yields spread. Thus, cointegration tests can be considered as a prior test to avoid spurious regressions (Granger, 1986) ${ }^{11}$.

Unit root tests will be carried out on the proposed series as a first step and subsequently the corresponding cointegration analysis will be performed.

\subsection{Unit roots}

Dickey-Fuller (Augmented Dickey-Fuller), Phillips-Perron and Kwiatkowski-PhillipsSchmidt-Shin tests (hereinafter, ADF, PP and KPSS, respectively) were used for establishing the order of integration of the variables.

One of the main drawbacks of the unit root tests is the possibility of not rejecting the nonstationary hypothesis due to the existence of structural breaks or outliers, which if were considered in the analysis could led to the rejection of that hypothesis.

In this sense, Perron (1989) shows that the ADF is sensitive to the presence of structural breaks and therefore, in case they exist, its conclusions could be erroneous for the studied series.

Different authors (Perron and Vogelsang, 1992; Jaén and Lopez, 2001) distinguish two types of breaks depending on their effects:

a) Additive outlier model (hereinafter, AO). Each break occurs in an instantaneous and precise way.

b) Innovative outlier model (hereinafter, IO). Each break occurs gradually, prolongating its effect throughout the time.

Some researchers criticize the IO due to the persistence of their effects (Kaiser and Maravall, 2001) and therefore the AO is preferred to the IO.

Furthermore, Glynnet al. (2007) distinguish between two types of models:

a) Models with exogenous breakpoints established by the researcher.

b) Models with endogenous breakpoints, determined by quantitative methods.

In this paper, we opted to use a model with endogenous breakpoints, because we thought that its definition has less subjectivity.

The existence of structural breaks in time series makes necessary to use different tests depending on the number of breaks, so the following test will be applied for one break and two breaks respectively: Perron and Vogelsang test (1992) (hereinafter, PV) and Clemente, Montañés and Reyes test (1998) (hereinafter, CMR).

\subsection{Cointegration}

Only those variables that have a unit root can be used in the Engle-Granger and GregoryHansen cointegration tests.

\footnotetext{
${ }^{11}$ In case of presence of non-stationary variables, the $R^{2}$ and $t$ statistics cannot be used as usual, since these statistics do not follow their standard distributions (Gujarati and Porter, 2010).
} 
The Engle-Granger test will be used for a first cointegration analysis without the presence of structural breaks. This analysis will be complemented with the Durbin-Watson test ${ }^{12}$. Possible structural breaks in the variables analysed and their possible influence on the cointegration relationship of the series will be studied later on.

The presence of structural breaks in the series could hide existing cointegration relationships among them, so Gregory and Hansen (1996) developed a cointegration model for being used with series with structural breaks.

\section{Empirical analysis}

\subsection{Order of integration of the variables}

The results of Table $1^{13}$ were obtained considering as a primary rule the preference for the ADF test when it indicated stationarity and for the structural break tests (particularly the AO) in other case; and as a secondary rule, comparing the results of the PP and KPSS tests to substantiate the valuations.

Table 1. Summary of the unit root tests results

\begin{tabular}{llll}
\hline \hline Variable & $\begin{array}{l}\text { Stationarity of the } \\
\text { variable in levels }\end{array}$ & $\begin{array}{l}\text { Stationarity of the variable } \\
\text { in first difference }\end{array}$ & $\begin{array}{l}\text { Stationarity of the } \\
\text { variable in second } \\
\text { difference }\end{array}$ \\
\hline \hline$D P R_{t}$ & No & Yes & Yes (most probable) \\
$D P U_{t}$ & No & Yes (most probable) & Yes \\
$I_{t}$ & No & Yes (most probable) & Yes \\
$P_{t}$ & No & Yes (most probable) & Yes \\
$F_{t}$ & No & Yes (most probable) & Yes \\
$S_{t}$ & No & Yes (most probable) & Yes \\
\hline \hline
\end{tabular}

To sum up, the unit root tests performed conclude the same order of integration - I(1) - for the variables $D P U_{t}, I_{t}, P_{t}, F_{t}$ and $S_{t}$; as an exception, the variable $D P R_{t}$ would be I(2).

The values of the order of integration obtained for the chosen variables are shared by other authors. Esteve and Tamarit (1994) note that the variable $D P U_{t}$ can be considered I(1). Meanwhile Bass and Esteve (1998) state that $I_{z}$ is I(1). Esteve et al. (1999) and Carrion-ISilvestre et al. (2004) point out that $P_{t}$, is an I(1) variable. Regarding $F_{t}$, Holmes (2006) studied the current account balance in Spain and identified it as non-stationary, as in most of the OECD countries. Finally, in relation to the public debt yields, De Andrés (2004) indicates that taking into account the rational expectations theory, interest rates have to be I(1). Figure 1 shows the evolution of this variable during the analysed period.

\footnotetext{
${ }^{12}$ Despite the existence of literature showing the use of the Johansen test with series of different size, it is only recommended for sample sizes greater than 100. Thus, as our sample size is 87 , such test will be omitted in this paper.

${ }^{13}$ See Annex 2 for more details of the unit root tests.
} 
Figure 1. 10 year public debt yield spread (Spanish versus German in \%)

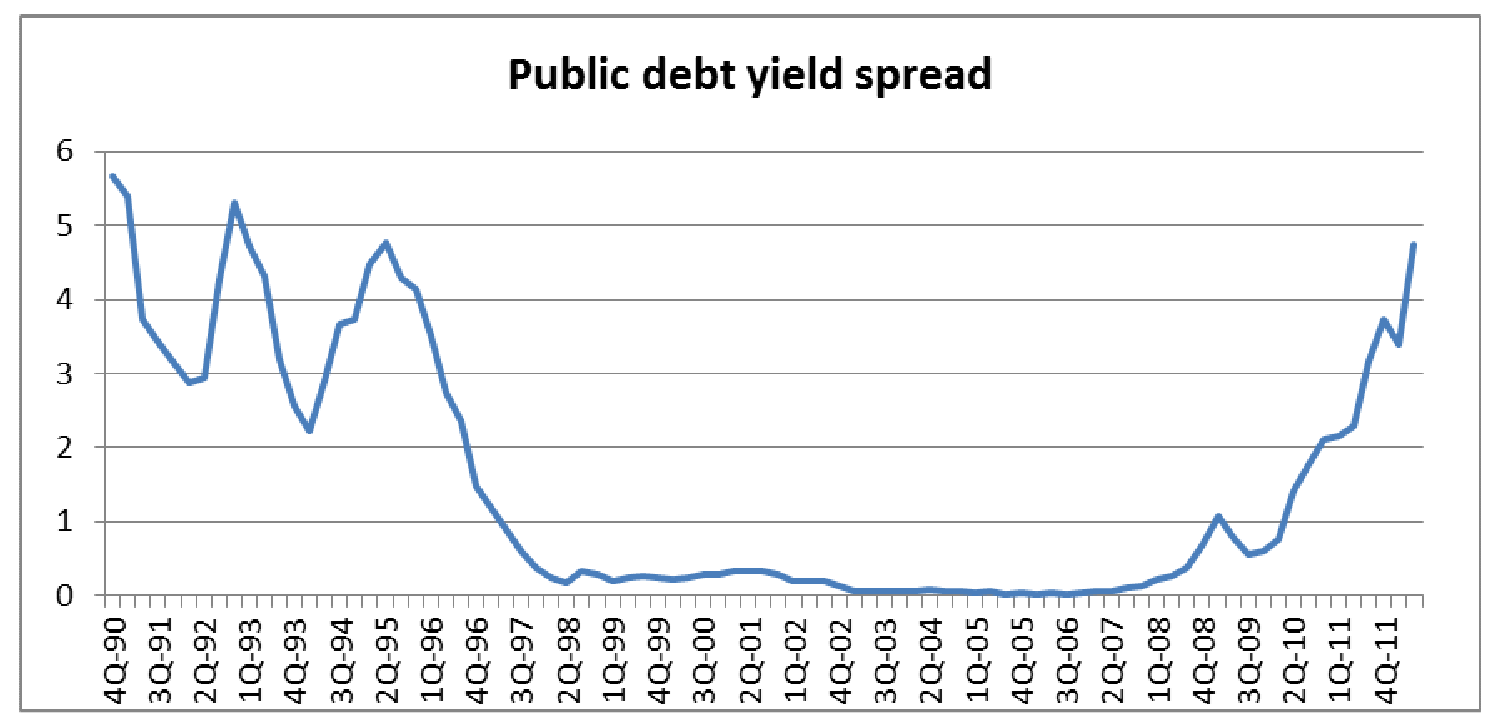

Source: http://www.bde.es/webbde/es/estadis/infoest/indeco.html

In this sense, although the analysis of the integration order of individual interest rate variables has been found in a literature review, this has not been the case for the spread. Anyway, the analysis of the individual interest rates can be used as a reference, since the spread could be seen as a linear combination of two non-stationary processes of the same integration order. In general, a combination like this obeys the condition:

$$
I(d)+I(d)=I(h \leq d)
$$

where $d$ is the same order of integration for the two variables to combine.

Therefore, in the particular case of the spread, $s_{t}$ if we consider this variable as the linear combination of two non-stationary processes I(1) - the individual performances of the public debt in Germany and Spain -, it should fulfil the relationship that follows:

$$
I(1)-I(1)=I(h \leq 1)
$$

Thus $h$-order of integration of the spread - could equal 1 (non-stationary) or 0 , (stationary), which would mean that there is a cointegration relationship among the long-term yields. From Table 1, it can be seen that the yield spread variable appears to be I(1), which indirectly leads to the conclusion that there is no cointegration relationship between the German and Spanish long-term debt yields.

Apart from that, the results of unit root tests considering one break (PV) and two breaks (CMR) revealed the existence of different breaks or 'outliers' in the analysed series (see Annex 2).

\subsection{Long-term relationships among variables}

Taking into account the findings presented in Table 1 and according to the Engle-Granger and Gregory-Hansen methodologies, the cointegration model would consist of $S_{t}$ as the dependent variable and $D P U_{t}, I_{t}, P_{t}$ y $F_{t}$ as regressors.

For the model estimated without breaks, the results obtained by the Engle-Granger test ${ }^{14}$ reflect that the hypothesis of cointegration between the series cannot be rejected at $5 \%$, both using AIC or BIC criteria ${ }^{15}$.

\footnotetext{
${ }^{14}$ See Annex 3.1.
} 
Moreover, the Durbin-Watson test for cointegration regression indicates that the hypothesis of cointegration among the variables cannot be rejected at $5 \%{ }^{16}$.

In the case of the model with breaks, the Gregory-Hansen test results at 5\% ${ }^{17}$ are presented in Table 2. It is verified the existence of two periods of structural breaks, one coinciding with the time of verification of the compliance with the terms of the convergence criteria established by the Maastricht Treaty ${ }^{18}$ and another that occurs with the start of the current economic crisis.

Table 2. Results from the Gregory-Hansen test

\begin{tabular}{lll}
\hline \hline Model & AIC & BIC \\
\hline \hline Change in level & No cointegration & $\begin{array}{l}\text { Contradictory results } \\
\text { Breaks: 4Q08 or 1Q09 } \\
\text { Change in level and trend }\end{array}$ \\
& No cointegration & $\begin{array}{l}\text { Contradictory results } \\
\text { Breaks: 1Q09 }\end{array}$ \\
Change in regime & Contradictory results \\
& Outlier: 3Q08 & Breaks: 3Q08 or 4Q08 \\
Change in regime and trend & No cointegration & Contradictory results \\
& & Breaks: 4Q95 or 2Q96 \\
\hline \hline
\end{tabular}

As Table 2 shows, it can be seen that there is no clear long-term relationship between the variable $S_{t}$ and the selected Spanish economy fundamentals, especially in the case of the BIC criteria.

\section{Conclusions}

This paper analyses the long-term relationship between the long term public debt yield spread (Spanish versus German), also known as risk premium, and some fundamentals of the Spanish economy.

First of all, the existence of a unit root in the series of Spanish public and private debt, inflation rate, unemployment rate, borrowing capacity and the yield spread of long-term debt Spanish and German is analysed. The tests reveal the existence of a unit root in all the abovementioned variables except for private debt.

The subsequent realization of the Engle-Granger test for non-stationary variables (with the spread as the dependent variable) leads to reject the hypothesis of no cointegration. The Gregory-Hansen test (considering structural breaks) produced contradictory results.

The cointegration analysis reveals that there is no evidence enough to show that the longterm risk premium behaviour is determined by the evolution of the Spanish economy fundamentals. This fact opens the door to the influence of other subjective factors (i.e. market

\footnotetext{
${ }^{15}$ Some authors find the so-called BIC criterion (Bayesian criterion or Schwarz criterion) more advisable than the AIC for not too big series. Both analyses have been carried out both in unit root tests and cointegration tests.

${ }^{16}$ The Durbin-Watson test (hereinafter DWRC) establishes as null hypothesis Ho: DW = 0, "the variables are not cointegrated" and as alternative hypothesis $\mathrm{H}_{1}$ : DW> 0 , i.e. "the variables are cointegrated." According to Gujarati (2003), in this test the critical value for a 5\% level is 0.386 . If the DW statistic does not exceed this value, Ho is not rejected and vice versa. As in our case $\mathrm{DW}=0.460>0.386$, it can be said that according to the test DWRC, the hypothesis that the variables are cointegrated cannot be rejected at $5 \%$.

${ }^{17}$ See Annex 3.2.

${ }^{18}$ One of the conditions established in the Maastricht Treaty was the economic convergence in relation to the long term interest rates. This treaty establishes that the average of the long-term nominal interest rate must not exceed by more than $2 \%$ the three best performing member states in terms of price stability.
} 
sentiment) and speculative factors (for example, the probability of disintegration of the euro area).

This way, according to the empirical results obtained from our study, the role of the spread in the implementation of economic policy measures must be relativized as an economic policy objective since it is not guaranteed that acting on the macroeconomic variables analysed will reduce significantly the risk premium.

These results should be taken into account when assessing the effectiveness and appropriateness of the austerity policies implemented by some peripheral economies, including the Spanish one, mainly focused on the need of reducing the risk premium.

However, in consequence of this analysis it must not be claimed that the reduction of imbalances in public finances is no longer a prioritary objective. Our results should be considered in relation to the discussion of the intensity and rhythm of fiscal adjustment over time and the need to combine fiscal consolidation with other kind of policies that compensate the recessionary effects associated with the process of fiscal consolidation.

Acknowledgements. The authors would like to thank the participants in the XI International Economic Policy Conference (Bilbao, Spain, 30-31 May 2013) and the two referees for their helpful comments in relation to a previous version of this paper.

\section{References}

Aßman, C. and Boysen-Hogrefe, J. (2009) Determinants of government bond spreads in the euro area: in good times as in bad, Kiel Working Papers, 1548.

Bank of Spain (2013) Los criterios de convergencia, available at: http://www.bde.es/bde/es/secciones/eurosistema/uem/criterios/

Bernanke, B. (1990) On the predictive power of interest rates and interest rate spreads, NBER Working Paper Series, 3486.

Carrion-i-Silvestre, J.L., Artís, M. and Sansó, A. (2004) Raíces unitarias y cambios estructurales en las macromagnitudes españolas, Revista de Economía Aplicada, 35, 527.

Clemente, J., Montañés, A. and Reyes, M. (1998) Testing for a unit root in variables with a double change in the mean, Economic Letters, 59, 175-182.

De Andrés, J. (2004) Un análisis de la curva de rendimientos en el mercado de deuda pública española a medio y largo plazo en el periodo 1993-2004, Economic Association of A Coruña - Economic Analysis Working Papers, 3(11).

Donoso, V. and Martín, V. (2010) La sostenibilidad del déficit exterior de España, Working Papers Instituto Complutense de Estudios Internacionales, 01/10, Madrid.

Düllmann, K. and Windfuhr, M. (2000) Credit spreads between German and Italian sovereign bonds: do one-factor affine models work?, Canadian Journal of Administrative Sciences, 2(17), 166-181.

Eichengreen, B. and Mody, A. (1998) What explains changing spreads on emerging-market debt: fundamentals or market sentiment, NBER Working Paper Series, № 3486.

Enders, W. (2010) Applied econometric time series, Ed. Wiley, Hoboken.

Engle, R.F. and Granger, C.W.J. (1987) Cointegration and error correction: representation, estimation and testing, Econometrica, 55, 251-276.

Esteve, V, Sapena, J. and Tamarit, C. (1999) Expectativas de devaluación y variables macroeconómicas: el caso de España, Información Comercial Española, 780, 35-48.

Esteve, V. and Tamarit, C. (1994) Determinantes de los tipos de interés reales a largo plazo en España, Revista de Economía Aplicada, 5, 27-50. 
European Central Bank (2013) European Central Bank monetary policy strategy, available at: http://www.ecb.int/ecb/educational/facts/monpol/html/mp_004.en.html

Favero, C.A., Giavazzi, F. and Spaventa, L. (1997) High yields: the spread on German interest rates, The Economic Journal, 107, 956-985.

Fontana, A. and Scheicher, M. (2010) An analysis of Euro Area sovereign CDS and their relation with government bonds, European Central Bank Working Papers Series, 1271.

Geyer, A., Kossmeier, S. and Pichler, S. (2004) Measuring systematic risk in EMU government yield spreads, Review of Finance, 8(2), 171-197.

Glynn, J., Perera, N. and Verma, R. (2007) Unit root tests and structural breaks: a survey with applications, Revista de Métodos Cuantitativos para la Economía y la Empresa, 3, 63-79.

Granger, C.W.J. (1986) Developments in the study of co-integrated economic variables, Oxford Bulletin of Economics and Statistics, 48, 213-228.

Gregory, A.W. and Hansen, B.E. (1996) Residual-based tests for cointegration in models with regime shifts, Journal of Econometrics, 70, 99-126.

Gujarati, D. (2003) Econometría. Ed. McGraw-Hill Interamericana, México D.F.

Gujarati, D. and Porter, D. (2010) Econometría. Ed. McGraw-Hill.

Holmes, M. (2006) How sustainable are OECD current account balances in the long run, The Manchester School, 74(5), 626-643.

Jaén, M. and López, E. (2001) Modelos econométricos de series temporales. Teoría y práctica. Septem Ediciones, Oviedo.

Kaiser, R. and Maravall, A. (2001) Seasonal outliers in time series, Bank of Spain Working Paper 9915.

Nieto-Parra, S. (2009) Who saw sovereign debt crisis coming?, Economía, 10(1), 125-169.

Perron, P. (1989) The great crash, the oil price shock, and the unit root hypothesis, Econometrica, 57(6), 1361-1401.

Perron, P. and Vogelsang, T.J. (1992) Nonstationarity and level shifts with an application to purchasing power parity, Journal of Business \& Economic Statistics, 10(3), 301-321.

Schulz, A. and Wolff, G.B. (2008) The German sub-national government bond market: structure, determinants of yield spreads and Berlin's forgone bail-out, Deutsche Bundesbank Discussion Paper, Series 1: Economic Studies, 06/2008. 


\section{Annex 1. Variables}

\begin{tabular}{lll}
\hline \hline Variable & Web links to get variables & Access Date \\
\hline \hline$D P R_{t}$ & http://www.bde.es/webbde/es/estadis/infoest/bolest3.html & 16 hov/2012 \\
$D P U_{t}$ & http://www.bde.es/webbde/es/estadis/infoest/htmls/cdp.html & 17 th/Nov/2012 \\
$I_{t}$ & http://www.bde.es/webbde/es/estadis/infoest/indeco.html & $18 \mathrm{th} / \mathrm{Nov} / 2012$ \\
$P_{t}$ & http://www.bde.es/webbde/es/estadis/infoest/sindi.html & $18 \mathrm{th} / \mathrm{Nov} / 2012$ \\
$F_{t}$ & http://www.bde.es/webbde/es/estadis/infoest/indeco.html & $16 \mathrm{th} / \mathrm{Jan} / 2013$ \\
$S_{t}$ & http://www.bde.es/webbde/es/estadis/infoest/indeco.html & 18th/Nov/2012 \\
\hline \hline
\end{tabular}

\section{Annex 2. Unit roots tests results}

\begin{tabular}{|c|c|c|c|c|c|c|}
\hline \multicolumn{7}{|c|}{$\begin{array}{l}\text { H0: Existence of unit root in all cases except K } \\
\text { AIC (BIC) criteria in ADF test, } 1 \text { st (2nd) raw. }\end{array}$} \\
\hline \multirow[t]{2}{*}{ Variables } & \multirow[t]{2}{*}{ ADF test } & \multirow[t]{2}{*}{ PP test } & \multirow[t]{2}{*}{ KPSS test } & \multicolumn{2}{|c|}{ Tests with breaks } & \multirow[t]{2}{*}{ Correlogram } \\
\hline & & & & $\mathrm{AO}$ & $\mathrm{IO}$ & \\
\hline$D P U_{t}$ & $\begin{array}{l}\text { Non stationary } \\
\text { Non stationary }\end{array}$ & Non stationary & Stationary & $\begin{array}{l}\text { Non stationary } \\
\text { Breaks: 1Q04 y 1Q10 }\end{array}$ & $\begin{array}{l}\text { Non stationary } \\
\text { Breaks: 3Q00 y 4Q08 }\end{array}$ & Non stationary \\
\hline$D P R_{t}$ & $\begin{array}{l}\text { Non stationary } \\
\text { Non stationary }\end{array}$ & Non stationary & Non stationary & $\begin{array}{l}\text { Non stationary } \\
\text { Breaks: } 1 \mathrm{Q} 01 \text { y } 3 \mathrm{Q} 06\end{array}$ & $\begin{array}{l}\text { Non stationary } \\
\text { Breaks: 1Q00 y 4Q04 }\end{array}$ & Non stationary \\
\hline$I_{t}$ & $\begin{array}{l}\text { Non stationary } \\
\text { Stationary }\end{array}$ & Non stationary & Stationary & $\begin{array}{l}\text { Non stationary } \\
\text { Breaks: 2Q96 y } 1 \mathrm{Q} 08\end{array}$ & $\begin{array}{l}\text { Non stationary } \\
\text { Breaks: 1Q95 y 2Q08 }\end{array}$ & Non stationary \\
\hline$P_{t}$ & $\begin{array}{l}\text { Non stationary } \\
\text { Non stationary }\end{array}$ & Non stationary & Stationary & $\begin{array}{l}\text { Non stationary } \\
\text { Breaks: 3Q99 y 2Q09 }\end{array}$ & $\begin{array}{l}\text { Non stationary } \\
\text { Breaks: 3Q98 y 2Q08 }\end{array}$ & Non stationary \\
\hline$F_{t}$ & $\begin{array}{l}\text { Non stationary } \\
\text { Non stationary }\end{array}$ & Non stationary & Non stationary & $\begin{array}{l}\text { Non stationary } \\
\text { Breaks: 2Q04 y 3Q08 }\end{array}$ & $\begin{array}{l}\text { Non stationary } \\
\text { Break: 3Q03 }\end{array}$ & Non stationary \\
\hline$S_{t}$ & $\begin{array}{l}\text { Non stationary } \\
\text { Non stationary }\end{array}$ & Non stationary & Non stationary & $\begin{array}{l}\text { Non stationary } \\
\text { Breaks: } 1 \text { Q97 y } 2 \text { Q09 }\end{array}$ & $\begin{array}{l}\text { Non stationary } \\
\text { Breaks: 2Q96 y 4Q09 }\end{array}$ & Non stationary \\
\hline $\mathrm{d} D P U_{t}$ & $\begin{array}{l}\text { Non stationary } \\
\text { Non stationary }\end{array}$ & Stationary & Stationary & \begin{tabular}{|l|} 
Stationary \\
Breaks: 2Q96 y 1 Q08
\end{tabular} & \begin{tabular}{|l|} 
Stationary \\
Breaks: 3Q96 y 2Q08
\end{tabular} & Non stationary \\
\hline$\overline{\mathrm{d}} D P R_{t}$ & $\begin{array}{l}\text { Non stationary } \\
\text { Non stationary }\end{array}$ & Stationary & Stationary & $\begin{array}{l}\text { Non stationary } \\
\text { Breaks: 2Q00 y 4Q09 }\end{array}$ & No breaks & Non stationary \\
\hline $\mathrm{d} / I_{t}$ & $\begin{array}{l}\text { Stationary } \\
\text { Stationary }\end{array}$ & Stationary & Stationary & $\begin{array}{l}\text { Non stationary } \\
\text { Breaks: } 1 \text { Q08 y } 3 \mathrm{Q} 09\end{array}$ & $\begin{array}{l}\text { Stationary } \\
\text { Breaks: 2Q08 y 2Q09 }\end{array}$ & Non stationary \\
\hline$\overline{\mathrm{d}} P_{t}$ & $\begin{array}{l}\text { Stationary } \\
\text { Stationary }\end{array}$ & Stationary & Stationary & $\begin{array}{l}\text { Non stationary } \\
\text { Breaks: 3Q93 Y 2Q07 }\end{array}$ & $\begin{array}{l}\text { Non stationary } \\
\text { Breaks: 4Q93 y 2Q07 }\end{array}$ & Non stationary \\
\hline$\overline{\mathrm{d}} F_{t}$ & $\begin{array}{l}\text { Stationary } \\
\text { Stationary }\end{array}$ & Stationary & Stationary & No breaks & $\begin{array}{l}\text { Non stationary } \\
\text { Breaks: 3Q95 y 4Q07 }\end{array}$ & Non stationary \\
\hline $\mathrm{d} S_{t}$ & $\begin{array}{l}\text { Non stationary } \\
\text { Stationary }\end{array}$ & Stationary & Non stationary & $\begin{array}{l}\text { Non stationary } \\
\text { Break: 3Q10 }\end{array}$ & No breaks & Non stationary \\
\hline $\mathrm{d} 2 D P U_{t}$ & $\begin{array}{l}\text { Stationary } \\
\text { Stationary }\end{array}$ & Stationary & Stationary & No breaks & $\begin{array}{l}\text { Stationary } \\
\text { Break: 4Q93 }\end{array}$ & Non stationary \\
\hline $\mathrm{d} 2 D P R_{t}$ & $\begin{array}{l}\text { Stationary } \\
\text { Stationary }\end{array}$ & Stationary & Stationary & No breaks & $\begin{array}{l}\text { Non stationary } \\
\text { Breaks: 3Q00 y 3Q01 }\end{array}$ & Non stationary \\
\hline $\mathrm{d} 2 I_{t}$ & $\begin{array}{l}\text { Stationary } \\
\text { Stationary }\end{array}$ & Stationary & Stationary & No breaks & No breaks & Non stationary \\
\hline $\mathrm{d} 2 P_{t}$ & $\begin{array}{l}\text { Stationary } \\
\text { Stationary }\end{array}$ & Stationary & Stationary & No breaks & No breaks & Non stationary \\
\hline$\overline{\mathrm{d} 2} F_{t}$ & $\begin{array}{l}\text { Stationary } \\
\text { Stationary }\end{array}$ & Stationary & Stationary & No breaks & No breaks & Non stationary \\
\hline $\mathrm{d} 2 S_{t}$ & $\begin{array}{l}\text { Stationary } \\
\text { Stationary }\end{array}$ & Stationary & Stationary & No breaks & No breaks & Stationary \\
\hline
\end{tabular}




\section{Annex 3. Cointegration tests results}

1. Engle-Granger test:

\begin{tabular}{ll}
\hline \hline Model & $\mathrm{S}_{\mathrm{t}}=\beta_{0}+\beta_{1} \cdot \mathrm{DPU} \mathrm{U}_{\mathrm{t}}+\beta_{2} \cdot \mathrm{I}_{\mathrm{t}}+\beta_{3} \cdot \mathrm{P}_{\mathrm{t}}+\beta_{4} \cdot \mathrm{F}_{\mathrm{t}}+\varepsilon_{\mathrm{t}}$ \\
Null hypothesis & $\varepsilon_{\mathrm{t}}$ has a unit root \\
Lag length (selected by AIC / SIC) & $3 / 1$ \\
Exogenous & None \\
Augmented Dickey-Fuller test statistic & $-4.813 /-5.098$ \\
Test critical values* & $-5.184(1 \%),-4.557(5 \%),-4.240(10 \%)$ \\
\hline \hline
\end{tabular}

* Source of the critical values: Enders (2010), p. 490 (Five variables, $\mathrm{T}=100$ )

2. Gregory-Hansen test:

2.1. AIC

\begin{tabular}{|c|c|c|c|c|c|c|c|c|c|c|}
\hline Model & $\begin{array}{l}\text { Lag } \\
\text { lenght }\end{array}$ & & est Stat & & Bre & kpoi & & & $\begin{array}{l}\text { itical v } \\
5 \text { and }\end{array}$ & \\
\hline Change in level & 8 & $\begin{array}{l}\text { ADF } \\
-4.08\end{array}$ & $\begin{array}{c}Z_{t} \\
-5.28\end{array}$ & $\begin{array}{c}\mathrm{Za} \\
-36.11\end{array}$ & $\begin{array}{l}\mathrm{ADF} \\
72\end{array}$ & $\begin{array}{l}\mathrm{Z}_{\mathrm{t}} \\
73\end{array}$ & $\begin{array}{l}\mathrm{Za} \\
73\end{array}$ & $\begin{array}{l}\text { ADF } \\
-6.05 \\
-5.56 \\
-5.31\end{array}$ & $\begin{array}{c}Z_{\mathrm{t}} \\
-6.05 \\
-5.56 \\
-5.31\end{array}$ & $\begin{array}{c}\mathrm{Za} \\
-70.18 \\
-59.40 \\
-54.38\end{array}$ \\
\hline $\begin{array}{l}\text { Change in level } \\
\text { and trend }\end{array}$ & 11 & -3.98 & -5.33 & -35.84 & 14 & 74 & 74 & $\begin{array}{l}-6.36 \\
-5.83 \\
-5.59\end{array}$ & $\begin{array}{l}-6.36 \\
-5.83 \\
-5.59\end{array}$ & $\begin{array}{l}-76.95 \\
-65.44 \\
-60.12\end{array}$ \\
\hline Change in regime & 3 & -6.90 & -5.83 & -39.55 & 72 & 72 & 72 & $\begin{array}{l}-6.92 \\
-6.41 \\
-6.17\end{array}$ & $\begin{array}{l}-6.92 \\
-6.41 \\
-6.17\end{array}$ & $\begin{array}{l}-90.35 \\
-78.52 \\
-75.56\end{array}$ \\
\hline $\begin{array}{l}\text { Change in regime } \\
\text { and trend }\end{array}$ & 3 & -5.69 & -6.10 & -44.86 & 20 & 21 & 21 & $\begin{array}{l}-7.31 \\
-6.84 \\
-6.58\end{array}$ & $\begin{array}{l}-7.31 \\
-6.84 \\
-6.58\end{array}$ & $\begin{array}{r}-100.69 \\
-88.47 \\
-82.30\end{array}$ \\
\hline
\end{tabular}

\subsection{BIC}

\begin{tabular}{|c|c|c|c|c|c|c|c|c|c|c|}
\hline Model & $\begin{array}{c}\text { Lag } \\
\text { lenght }\end{array}$ & & st Stati & & Bre & kpoi & & & $\begin{array}{l}\text { itical v } \\
5 \text { and }\end{array}$ & $\begin{array}{l}\text { lues } \\
0 \%)\end{array}$ \\
\hline Change in level & 3 & $\begin{array}{l}\text { ADF } \\
-6.51\end{array}$ & $\begin{array}{c}\mathrm{Z}_{\mathrm{t}} \\
-5.28\end{array}$ & $\begin{array}{c}\mathrm{Za} \\
-36.11\end{array}$ & $\begin{array}{c}\text { ADF } \\
74\end{array}$ & $\begin{array}{l}\mathrm{Z}_{\mathrm{t}} \\
73\end{array}$ & $\begin{array}{l}\mathrm{Za} \\
73\end{array}$ & $\begin{array}{l}\text { ADF } \\
-6.05 \\
-5.56 \\
-5.31\end{array}$ & $\begin{array}{c}\mathrm{Z}_{\mathrm{t}} \\
-6.05 \\
-5.56 \\
-5.31\end{array}$ & $\begin{array}{c}\mathrm{Za} \\
-70.18 \\
-59.40 \\
-54.38\end{array}$ \\
\hline $\begin{array}{l}\text { Change in level } \\
\text { and trend }\end{array}$ & 3 & -6.25 & -5.33 & -35.84 & 74 & 74 & 74 & $\begin{array}{l}-6.36 \\
-5.83 \\
-5.59\end{array}$ & $\begin{array}{l}-6.36 \\
-5.83 \\
-5.59\end{array}$ & $\begin{array}{l}-76.95 \\
-65.44 \\
-60.12\end{array}$ \\
\hline Change in regime & 3 & -7.39 & -5.83 & -39.55 & 73 & 72 & 72 & $\begin{array}{l}-6.92 \\
-6.41\end{array}$ & $\begin{array}{l}-6.92 \\
-6.41\end{array}$ & $\begin{array}{l}-90.35 \\
-78.52\end{array}$ \\
\hline $\begin{array}{l}\text { Change in regime } \\
\text { and trend }\end{array}$ & 3 & -7.13 & -6.10 & -44.86 & 23 & 21 & 21 & $\begin{array}{l}-6.17 \\
-7.31 \\
-6.84 \\
-6.58\end{array}$ & $\begin{array}{l}-6.17 \\
-7.31 \\
-6.84 \\
-6.58\end{array}$ & $\begin{array}{r}-75.56 \\
-100.69 \\
-88.47 \\
-82.30\end{array}$ \\
\hline
\end{tabular}

